\title{
Hygiene Assessment of the Performance of Food Safety Management System Implemented by Abattoirs in Edo State, Nigeria
}

\author{
${ }^{* 1}$ AKINNIBOSUN, FI.; ${ }^{2}$ IMADE, OS. \\ ${ }^{I}$ Department of Microbiology, Faculty of Life Sciences, University of Benin, P.M.B 1154, Benin City, Edo State, Nigeria. \\ ${ }^{2}$ Department of Biological Sciences, College of Natural and Applied Sciences, Igbinedion University, Okada, Edo State, Nigeria. \\ ${ }^{*}$ Corresponding author's e-mail: fakinnibosun@yahoo.co.uk
}

\begin{abstract}
The aim of this paper is to present a measure of the performance of Food Safety Management System (FSMS) implemented in five municipal abattoirs situated in Edo State, Nigeria. Hygiene status of the abattoirs was assessed by a quantitative interpretation of observations obtained from visual inspection of abattoir's operations by a 3-member panelist. Hygiene assessment was then confirmed by microbiological performance criteria that were based on standard predetermined guide values. Results obtained from present study indicated that the overall hygienic status (hygienic status of the lairage and processing environment were $17.8 \%$ and $12.9 \%$ respectively) of the abattoirs was bad, indicating that no systems and no written records exist, and lay workers without any training were expected to apply hygiene standards. Results also revealed that microbial safety level was estimated at 0.83 , indicating that values of microbiological parameters examined grossly exceeded the safe limit and improvements were needed to be made on multiple control activity of the food safety plan. Values of the hygienic status and microbial safety level, therefore, corroborate that the overall performance of FSMS implemented in the abattoirs in Edo State was generally evaluated as poor. C JASEM
\end{abstract}

http://dx.doi.org/10.4314/jasem/v19i3.23

KEY WORDS: Microbial contamination, Bacteria, fungi, abattoir, food safety

\section{Introduction}

The provision of facilities and services in the cities and neighborhoods is crucial to their sustainability and efficiency. Abattoir is one of the facilities available in most towns and cities (Alonge, 2001), as the slaughtering of animals to supply meat for human consumption in them is a common practice in Nigeria. The growing concern about meat safety to public health has provided the impetus for a Food Safety Management System (FSMS), which entails Good Hygienic Practices (GHP) and application of Hazard Analysis Critical Control Points (HACCP) system to animal slaughtering and processing in abattoirs (Luning and Marcelis, 2007; Jacxsens et al., 2009, Govender, 2014). The goal of employing GHP and HACCP system for slaughter operations, therefore, is to prevent, eliminate, or reduce the incidence and levels of microorganisms pathogenic to humans.

Growing population with increase in demand for meat has resulted in increased abattoir related infections (Bwala et al., 2015) and has attracted interventions in many developed countries (Anonymous, 2001). On the contrary, little intervention or response has been made in the developing nations. Unlike in most developed countries, Edwards et al., (1979) reported that the slaughter of animals in abattoirs of developing countries was carried out in unsuitable buildings by untrained slaughter men and butchers that were unaware of sanitary and HACCP principles.

In Nigeria, despite lack of pathological reports, work done by various researchers has shown the possibility of contamination of meat products by various pathogens. For instance, Fasanmi et al., (2010) reported that Nigerian meat was contaminated with bacterial and fungal pathogens at levels that could easily pose a health risk to immuno-compromised individuals. The study indicated that microorganisms, particularly, Bacillus, Escherichia, Salmonella, Pseudomonas, Staphylococcus, Aspergillus, Fusarium, Rhizopus, and Saccharomyces species were the main etiologic agents. In view of the public health concern arising from slaughtering and processing of animals in abattoirs and the usefulness of GHP and HACCP system with respect to hygiene and food safety, this study was carried out by performing a comprehensive hygiene assessment to ascertain the hygienic status of abattoirs in Edo State, Nigeria, and to measure the performance of the FSMS implemented in these abattoirs.

\section{MATERIALS AND METHODS}

Media preparation: Nutrient agar (Lab M, Topley House, Lancashire, UK), MacConkey agar (Lab M, Topley House, Lancashire, UK), Eosine Methylene Blue (EMB) agar (Lab M, Topley House, Lancashire, UK), Buffered peptone water (Fluka Chemical, 
Sigma Aldrich, Germany) used in this research were prepared according to manufacturer's instruction.

Study sites: Municipal abattoirs situated in Edo State, Nigeria were used for this study. Cattles provide the main source of beef processed in these abattoir. The abattoirs had open spaces enclosed with covered roofs. The floors were made of concrete, and cattle dung was usually deposited very close to the abattoirs. Boreholes provide the source of water.

Study design: The abattoirs were visited once weekly between July and December, 2013 covering the wet and harmattan seasons. On each visit 10 cattle were randomly selected from the lot of cattle to be slaughtered, which often ranged between $70-80$ heads of cattle per day. Cumulatively, from a total population of 10,000 cattle that can be slaughtered over the period, a sample size of 1250 cattle was employed for microbial analysis, which was used to validate the initial visual inspection of abattoir's environment.

Visual inspection of abattoir's environment: The hygienic status of the abattoirs in the present study was subjectively assessed via visual inspection of the lairage and processing environment by a 3 - member panelist, according to method of Pinillos and Jukes, 2008 .

Collection of samples from carcasses: Samples were collected from two critical sites (briskets and flanks) on the carcasses during three critical processing operations. The sampling was done by swabbing a $100 \mathrm{~cm}^{2}$ area of each sampling site with 10 sterile cotton tipped sticks which had been pre-moistened with $2 \% \mathrm{~W} / \mathrm{V}$ peptone water according to the technique specified by ISO 17604:2003 (ISO, 2003). Area of sampling was delimited by sterile templates. After swabbing, the swab sticks were put into a sterile container containing $100 \mathrm{ml}$ of $2 \% \mathrm{~W} / \mathrm{V}$ peptone water, and was stored on ice while being transported to the laboratory. Microbial analysis was then conducted within 6 hours of sampling.

Collection of samples from carcass contact surfaces: Samples were collected from dispatch cans used for packing the slaughtered carcasses, floor area where the carcasses were slaughtered, as well as from the butcher's knives and hands. Sampling was done by swabbing $25 \mathrm{~cm}^{2}$ area of the contact surfaces with 5 sterile $2 \% \mathrm{~W} / \mathrm{V}$ peptone water according to the method specified by ISO 18593:2004 (ISO, 2004). Area of sampling was delimited by sterile templates. After swabbing, the swab sticks were put into a sterile container containing $100 \mathrm{ml}$ of $2 \% \mathrm{~W} / \mathrm{V}$ peptone water, and was stored on ice while being transported to the laboratory. Microbial analysis was then conducted within 6 hours of sampling.
Microbial analysis: Microbial analysis was conducted on the carcasses and carcass contact surfaces. Total aerobic viable counts (TAVC), Total coliform counts (TCC), and Escherichia coli counts (ECC) were performed on the carcasses at two critical sites (briskets and flanks) during skinning (preevisceration), evisceration, and splitting (postevisceration) operations, and also on the contact surfaces during processing at the abattoirs. Counting was done using the pour plate method (Barrow and Feltham, 2003). Pure cultures of bacteria isolated from the samples were subjected to various morphological and biochemical characterization tests to confirm the identity of bacteria according to guidelines in Barrow and Feltham, (2003). Microbiological performance criteria used for the measurement of the food safety system (Good Hygienic Practices (GHP) and Hazard Analysis Critical Control Point (HACCP) implemented in the abattoirs examined was based on standard predetermined guide values (McEvoy et al., 2004).

Statistical analysis of data: All the bacteria counts were transformed to $\log _{10}$ values. Mean $\log (\mathrm{X})$ and standard deviations (S) were calculated. Log mean $(\log$ A) were calculated for total aerobic viable counts (TAVC), total coliform counts (TCC), and Escherichia coli counts (ECC) of carcasses and carcass contact surfaces, since bacteria were recovered from more than $80 \%$ of the samples collected. Log A was calculated from (X) and (S) using the formulae: $\log A=X+I n 10 \times S^{2} / 2$ (Kilsby and Pugh, 1981).

\section{RESULTS AND DISCUSSION}

Hygiene assessment of the abattoir's environment by visual inspection A comprehensive assessment of the lairage and processing environments of the abattoirs was carried out to determine the hygienic status of abattoirs in Edo State, Nigeria. Data obtained from a subjective visual inspection of the lairage by a 3member panelist, as shown on the score sheet in Table 1, were interpreted using an evaluation grid. The highest level of hygiene at the lairage was recorded in December $(19.78 \%)$, while it was lowest in August $(16.58 \%)$. The mean cumulative scores obtained in July, September, October, and November were $16.73 \%, 17.75 \%, 17.53 \%$, and $18.42 \%$ respectively. Overall mean cumulative scores for the entire period of study (July to December) was 17.80 $\%$. When all the hygiene assessment scores were matched on the evaluation grid to determine the hygienic status of the lairage environments, they indicated that the lairage environments was in a bad state - a condition in which no systems and no written records exist, and lay workers without any training were expected to apply hygiene standards. 
Data obtained from visual inspection of the processing environments by the 3-member panelist, as shown on the score sheet in Table 2, were interpreted by the evaluation grid. In October, the processing environments had the highest level of hygiene $(14.44 \%)$, while it was lowest in July (11.37 $\%) .12 .04 \%, 12.41 \%, 12.92 \%$, and $14.20 \%$ were respectively recorded as the mean cumulative scores in August, September, November, and December. Overall mean cumulative scores for the entire period of study (July to December) was $12.90 \%$. The processing environments were also in a bad state, as indicated by the evaluation grid.

\section{Evaluation grid}

Scores
$>85 \leq 100$
$>65 \leq 85$
$>40 \leq 65$
$>20 \leq 40$
$>5 \leq 20$
$<5$

\section{Hygienic Status}

Inference

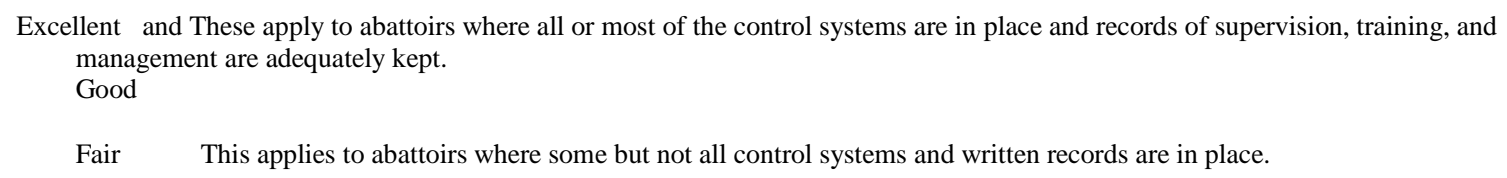

Poor This relates to abattoirs where structural requirements are adhered to, meat inspection services are limited to carcass inspection, training is left over to senior workers with limited expertise to train newly appointed personnel.

Bad This is allocated where no systems exist, no written records and lay workers without any training are expected to apply hygiene Standard

Critical This is allocated where it is virtually impossible to continue slaughter without causing contamination and therefore producing unsafe meat . "Critical" warrants a stop slaughter directive or even withdrawal of registration.

Hygiene assessment of the abattoirs using microbiological criteria: Table 3 represents mean values of TAVC, TCC, and ECC during carcass sampling. Log. mean ( $\log$ A) TAVC values for the briskets ranged from 4.29 to 8.31 ; while it was between 4.00 and 14.04 for the flanks. Log A TCC values for the briskets and flanks ranged from 0.95 to 3.11, and from 0.89 to 3.59 for briskets and flanks respectively; while log A ECC values was between 0.25 and 2.20 for briskets, as well as between 0.35 and 1.80 for flanks. When $\log$ A values of TAVC obtained during the processing operations were compared with the microbiological performance limit $\left(10 \mathrm{cfu} / \mathrm{cm}^{2}\right)$, all the values were within the acceptable limit, except for flanks which had a value of $14.04 \mathrm{cfu} / \mathrm{cm}^{2}$ ) during splitting. However, except for the skinning operation, all the $\log$ A TCC and ECC values significantly exceeded the acceptable limit $\left(1 \mathrm{cfu} / \mathrm{cm}^{2}\right)$.

Mean values of TAVC, TCC, and ECC during sampling of carcass contact surfaces is represented in Table 4. Log A TAVC values for the carcasss contact surfaces ranged from $25.51 \mathrm{cfu} / \mathrm{cm}^{2}$ to $33.20 \mathrm{cfu} / \mathrm{cm}^{2}$. Log A TCC values were between $3.33 \mathrm{cfu} / \mathrm{cm}^{2}$ and $4.23 \mathrm{cfu} / \mathrm{cm}^{2}$, while $\log$ A ECC values ranged from $2.14 \mathrm{cfu} / \mathrm{cm}^{2}$ to $2.40 \mathrm{cfu} / \mathrm{cm}^{2}$. All the $\log$ A TAVC values significantly exceeded the microbiological performance limit of $10 \mathrm{cfu} / \mathrm{cm}^{2}$. All the $\log$ A TCC and ECC values also exceeded the acceptable limit of $1 \mathrm{cfu} / \mathrm{cm}^{2}$. 
Table 1 : Hygiene assessment score sheet of the lairage environment and it evaluation grid

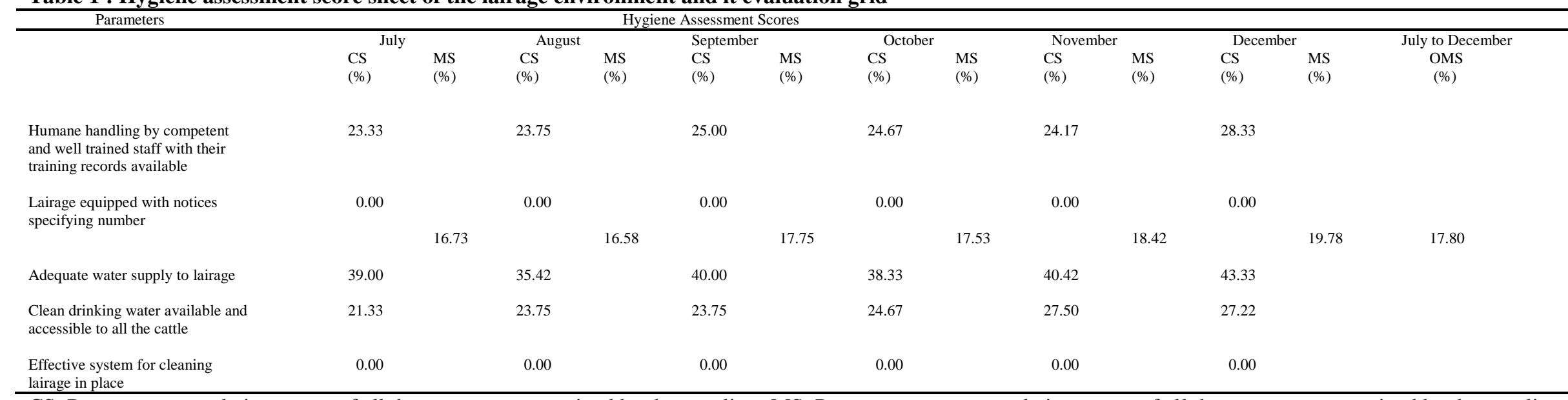

CS: Percentage cumulative scores of all the parameters examined by the panelists; MS: Percentage mean cumulative scores of all the parameters examined by the panelists

OMS: Overall percentage mean cumulative scores for the entire period of study.

${ }^{* 1}$ AKINNIBOSUN, FI.; ${ }^{2} I M A D E, O S$. 
Table 2: Hygiene assessment score sheet of the processing environment

\begin{tabular}{|c|c|c|c|c|c|c|c|c|c|c|c|c|c|}
\hline \multirow[t]{3}{*}{ Parameters } & \multicolumn{12}{|c|}{ Hygiene Assessment Scores } & \multirow{3}{*}{$\begin{array}{c}\text { July to } \\
\text { December } \\
\text { OMS } \\
(\%)\end{array}$} \\
\hline & \multicolumn{2}{|c|}{ July } & \multicolumn{2}{|c|}{ August } & \multicolumn{2}{|c|}{ September } & \multicolumn{2}{|c|}{ October } & \multicolumn{2}{|c|}{ November } & \multicolumn{2}{|c|}{ December } & \\
\hline & $\begin{array}{l}\mathrm{CS} \\
(\%)\end{array}$ & $\begin{array}{l}\text { MS } \\
(\%)\end{array}$ & $\begin{array}{l}\mathrm{CS} \\
(\%)\end{array}$ & $\begin{array}{l}\text { MS } \\
(\%)\end{array}$ & $\begin{array}{l}\mathrm{CS} \\
(\%)\end{array}$ & $\begin{array}{l}\text { MS } \\
(\%)\end{array}$ & $\begin{array}{l}\mathrm{CS} \\
(\%)\end{array}$ & $\begin{array}{l}\text { MS } \\
(\%)\end{array}$ & $\begin{array}{l}\mathrm{CS} \\
(\%)\end{array}$ & $\begin{array}{l}\text { MS } \\
(\%)\end{array}$ & $\begin{array}{l}\mathrm{CS} \\
(\%)\end{array}$ & $\begin{array}{l}\text { MS } \\
(\%)\end{array}$ & \\
\hline $\begin{array}{l}\text { Humane handling of cattle by well } \\
\text { trained staff and their training records }\end{array}$ & 31.33 & & 33.33 & & 28.33 & & 34.33 & & 32.92 & & 39.44 & & \\
\hline $\begin{array}{l}\text { Well trained personnel and } \\
\text { supervision to ensure that correct } \\
\text { procedures are used }\end{array}$ & 27.00 & & 24.58 & & 23.75 & & 35.33 & & 26.25 & & 26.11 & & \\
\hline Sterilization of bleeding knives & 0.00 & & 0.00 & & 0.00 & & 0.00 & & 0.00 & & 0.00 & & \\
\hline $\begin{array}{l}\text { Knives sterilized after opening lines } \\
\text { before flaying }\end{array}$ & 0.00 & & 0.00 & & 0.00 & & 0.00 & & 0.00 & & 0.00 & & \\
\hline $\begin{array}{l}\text { Incidental contamination removed } \\
\text { by trimming only }\end{array}$ & 18.67 & 11.37 & 20.83 & 12.04 & 22.08 & 12.41 & 23.67 & 14.44 & 20.42 & 12.92 & 21.67 & 14.20 & 12.90 \\
\hline $\begin{array}{l}\text { Standard operational procedure for } \\
\text { contaminated carcasses }\end{array}$ & 12.67 & & 12.92 & & 15.42 & & 13.67 & & 12.92 & & 12.22 & & \\
\hline Continuous cleaning process in place & 0.00 & & 0.00 & & 0.00 & & 0.00 & & 0.00 & & 0.00 & & \\
\hline $\begin{array}{l}\text { Carcasses washed sufficiently to } \\
\text { remove blood on neck area and visceral } \\
\text { pleura }\end{array}$ & 12.67 & & 16.67 & & 22.08 & & 23.00 & & 23.75 & & 28.33 & & \\
\hline $\begin{array}{l}\text { All sterilizers in working areas are } \\
\geq 82^{\circ} \mathrm{C} \text { with proper overflow }\end{array}$ & 0.00 & & 0.00 & & 0.00 & & 0.00 & & 0.00 & & 0.00 & & \\
\hline
\end{tabular}

CS: Percentage cumulative scores of all the parameters examined by the panelists; MS: Percentage mean cumulative scores of all the parameters examined by the panelists; OMS: Overall percentage mean cumulative scores for the entire period of sampling. See details of evaluation grid in Table 1.

\footnotetext{
${ }^{*}$ AKINNIBOSUN, FI.; ${ }^{2} I M A D E$, OS.
} 
Table 3: TAVC, TCC and ECC on carcasses obtained from abattoirs in Edo State, Nigeria

\begin{tabular}{|c|c|c|c|c|c|c|c|c|c|}
\hline \multirow{2}{*}{\begin{tabular}{l|} 
Processing \\
Operations
\end{tabular}} & \multirow{2}{*}{$\begin{array}{l}\text { Month(s) of } \\
\text { visitations }\end{array}$} & \multirow[t]{2}{*}{$\mathbf{N}$} & \multirow{2}{*}{$\begin{array}{l}\text { Critical } \\
\text { Sampling } \\
\text { Locations }\end{array}$} & \multicolumn{2}{|c|}{ TAVC values } & \multicolumn{2}{|c|}{ TCC values } & \multicolumn{2}{|c|}{ ECC values } \\
\hline & & & & $\begin{array}{l}\text { Mean TAVC } \\
\left(\log \mathrm{cfu} / \mathrm{cm}^{2}\right)\end{array}$ & $\begin{array}{l}\log \mathbf{A} \\
\left(\mathbf{c f u} / \mathrm{cm}^{2}\right)\end{array}$ & $\begin{array}{l}\text { Mean TCC } \\
\left(\log \mathrm{cfu} / \mathrm{cm}^{2}\right)\end{array}$ & $\begin{array}{l}\log \mathbf{A} \\
\left(\mathbf{c f u} / \mathrm{cm}^{2}\right)\end{array}$ & $\begin{array}{l}\text { Mean ECC } \\
\left(\log \mathbf{c f u} / \mathrm{cm}^{2}\right)\end{array}$ & $\begin{array}{l}\log \mathbf{A} \\
\left(\mathbf{c f u} / \mathrm{cm}^{2}\right)\end{array}$ \\
\hline $\begin{array}{l}\text { Skinning (pre- } \\
\text { evisceration) }\end{array}$ & July - December & 1,250 & $\begin{array}{l}\text { Brisket } \\
\text { Flank }\end{array}$ & $\begin{array}{l}3.52 \pm 0.82 \\
3.28 \pm 0.79\end{array}$ & $\begin{array}{l}4.29 \\
4.00\end{array}$ & $\begin{array}{l}0.74 \pm 0.43 \\
0.66 \pm 0.45\end{array}$ & $\begin{array}{l}0.95 \\
0.89\end{array}$ & $\begin{array}{l}0.18 \pm 0.24 \\
0.25 \pm 0.29\end{array}$ & $\begin{array}{l}0.25 \\
0.35\end{array}$ \\
\hline Evisceration & July - December & 1,250 & $\begin{array}{l}\text { Brisket } \\
\text { Flank }\end{array}$ & $\begin{array}{l}3.93 \pm 1.85 \\
3.97 \pm 2.05\end{array}$ & $\begin{array}{l}7.87 \\
8.81\end{array}$ & $\begin{array}{l}1.58 \pm 1.17 \\
1.63 \pm 0.93\end{array}$ & $\begin{array}{l}3.16 \\
2.63\end{array}$ & $\begin{array}{l}1.35 \pm 0.86 \\
1.36 \pm 0.57\end{array}$ & $\begin{array}{l}2.20 \\
1.73\end{array}$ \\
\hline $\begin{array}{l}\text { Splitting (Post- } \\
\text { evisceration) }\end{array}$ & July - December & 1,250 & $\begin{array}{l}\text { Brisket } \\
\text { Flank }\end{array}$ & $\begin{array}{l}3.98 \pm 1.94 \\
4.16 \pm 2.93\end{array}$ & $\begin{array}{r}8.31 \\
14.04\end{array}$ & $\begin{array}{l}1.61 \pm 1.14 \\
1.85 \pm 1.23\end{array}$ & $\begin{array}{l}3.11 \\
3.59\end{array}$ & $\begin{array}{l}1.39 \pm 0.71 \\
1.38 \pm 0.60\end{array}$ & $\begin{array}{l}1.97 \\
1.80\end{array}$ \\
\hline
\end{tabular}

Table 4: TAVC, TCC and ECC on Carcass contact surfaces obtained from abattoirs in Edo State, Nigeria

\begin{tabular}{|c|c|c|c|c|c|c|c|c|}
\hline \multirow{2}{*}{$\begin{array}{l}\text { Contact } \\
\text { Surfaces }\end{array}$} & \multirow{2}{*}{$\begin{array}{l}\text { Month(s) of } \\
\text { visitations }\end{array}$} & \multirow[t]{2}{*}{$\mathbf{N}$} & \multicolumn{2}{|c|}{$\begin{array}{l}\text { TAVC values } \\
\end{array}$} & \multicolumn{2}{|c|}{$\begin{array}{c}\text { TCC values } \\
\end{array}$} & \multicolumn{2}{|c|}{ ECC values } \\
\hline & & & $\begin{array}{l}\text { Mean TAVC } \\
\left(\log \mathrm{cfu} / \mathrm{cm}^{2}\right)\end{array}$ & $\begin{array}{l}\log \mathbf{A} \\
\left(\mathbf{c f u} / \mathbf{c m}^{2}\right) \\
\end{array}$ & $\begin{array}{l}\text { Mean TCC } \\
\left(\log \mathrm{cfu}^{2} / \mathrm{cm}^{2}\right)\end{array}$ & $\begin{array}{l}\log \mathbf{A} \\
\left(\mathbf{c f u} / \mathbf{c m}^{2}\right)\end{array}$ & 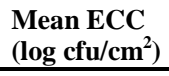 & $\begin{array}{l}\log A \\
\left(\text { cfu/ }^{\prime} \mathrm{cm}^{2}\right)\end{array}$ \\
\hline Floor & July - December & 1,250 & $4.42 \pm 5.00$ & 33.20 & $1.91 \pm 1.42$ & 4.23 & $1.59 \pm 0.84$ & 2.40 \\
\hline Dispatch cans & July - December & 1,250 & $4.36 \pm 4.55$ & 28.20 & $1.86 \pm 1.33$ & 3.90 & $1.54 \pm 0.73$ & 2.15 \\
\hline Knives & July - December & 1,250 & $4.29 \pm 4.36$ & 26.18 & $1.82 \pm 1.30$ & 3.77 & $1.53 \pm 0.74$ & 2.16 \\
\hline Butcher's hands & July - December & 1,250 & $4.32 \pm 4.29$ & 25.51 & $1.83 \pm 1.14$ & 3.33 & $1.42 \pm 0.79$ & 2.14 \\
\hline
\end{tabular}

${ }^{* 1}$ AKINNIBOSUN, FI.; ${ }^{2} I M A D E, O S$. 
Table 5: Microbial safety level profile

\begin{tabular}{|c|c|c|c|c|c|c|c|}
\hline Sampling locations & & Safety level scores for & ological pa & & & & Overall microbial safety level \\
\hline & TAVC & CTAVC & TCC & CTCC & ECC & CECC & \\
\hline $\begin{array}{r}\text { Skinning (Brisket) } \\
\text { (Flank) }\end{array}$ & $\begin{array}{l}2.75 / 3.00 \\
2.83 / 3.00\end{array}$ & & $\begin{array}{l}3.00 / 3.00 \\
3.00 / 3.00\end{array}$ & & $\begin{array}{l}2.80 / 3.00 \\
3.00 / 3.00\end{array}$ & & \\
\hline $\begin{array}{r}\text { Evisceration (Brisket) } \\
\text { (Flank) }\end{array}$ & $\begin{array}{l}2.22 / 3.00 \\
2.17 / 3.00\end{array}$ & & $\begin{array}{l}0.00 / 3.00 \\
1.00 / 3.00\end{array}$ & & $\begin{array}{l}0.00 / 3.00 \\
0.00 / 3.00\end{array}$ & & \\
\hline $\begin{array}{c}\text { Splitting (Brisket) } \\
\text { (Flank) }\end{array}$ & $\begin{array}{l}2.20 / 3.00 \\
0.00 / 3.00\end{array}$ & $12.1 / 30(1.21 / 3)$ & $\begin{array}{l}0.00 / 3.00 \\
0.00 / 3.00\end{array}$ & $7.0 / 30(0.70 / 3)$ & $\begin{array}{l}0.00 / 3.00 \\
0.00 / 3.00\end{array}$ & $5.80 / 30(0.58 / 3)$ & $24.9 / 90(0.83 / 3)$ \\
\hline Floor & $0.00 / 3.00$ & & $0.00 / 3.00$ & & $0.00 / 3.00$ & & \\
\hline Dispatch cans & $0.00 / 3.00$ & & $0.00 / 3.00$ & & $0.00 / 3.00$ & & \\
\hline Knives & $0.00 / 3.00$ & & $0.00 / 3.00$ & & $0.00 / 3.00$ & & \\
\hline Butcher's hands & $0.00 / 3.00$ & & $0.00 / 3.00$ & & $0.00 / 3.00$ & & \\
\hline
\end{tabular}

Classification of microbial safety level scores: level scores of 3/3 indicates that microbiological performance criteria were respected and no improvement was needed; level scores of $\geq 2 / 3$ indicates that values of microbiological parameters exceeded the safe limit and improvements were needed to be made on a single control activity of the food safety plan; level scores of $\geq 1 / 3 \leq 2 / 3$ shows that that values of microbiological parameters exceeded the safe limit and improvements were needed to be made on multiple control activity of the food safety plan. $<1$ also shows that values of microbiological parameters grossly exceeded the safe limit and improvements were needed to be made on multiple control activity of the food safety plan. CTAVC, CTCC, and CECC represent cumulative safety level scores for total aerobic viable counts, total coliform counts, and Escherichia coli counts respectively.

\footnotetext{
${ }^{*}$ AKINNIBOSUN, FI.; ${ }^{2} I M A D E$, OS.
} 
Table 5 represents the microbial safety level profile of the abattoirs. Cumulative safety level scores for total aerobic viable counts, total coliform counts, and Escherichia coli counts were 1.21, 0.7, and 0.58 respectively. Overall microbial safety level for the entire period of study (July to December) was 0.83, indicating that the values of microbiological parameters obtained in the present study grossly exceeded the safe limit and improvements were therefore needed to be made on multiple control activity of the food safety plan.

The overall poor hygienic status of the abattoirs in Edo State, Nigeria, as indicated by hygiene assessment scores of $17.80 \%$ and $12.90 \%$ for the lairage and processing environments respectively (Tables 1 and 2), was verified by the microbial analysis (Tables 3 and 4) conducted on the carcasses and carcass conduct surfaces as demanded by Codex Alimentarius (Hong et al., 2008; Jacxsens et al., 2009).

Findings of the present study were generally in accordance with those carried out by Gill in 2000, who reported microbial contamination of meat during slaughtering and dressing of cattle. The data obtained showed heterogeneity of microbial contamination on carcasses after skinning, evisceration, and splitting operations. From the data obtained (Table 3), there was no statistically significant variation in the overall microbiological performance of the skinning operation when compared to the slaughter house studied by McEvoy et al., (2004). The log A TAVC after skinning operation were $4.29 \mathrm{cfu} / \mathrm{cm}^{2}$ in the abattoirs examined in the present study and 4.0 $\mathrm{cfu} / \mathrm{cm}^{2}$ in the abattoir studied by McEvoy et al. (2004).

The contamination levels were however, significantly higher in the abattoirs of the present study when the microbial values obtained after evisceration and splitting operations were compared to results obtained by McEvoy et al. (2004). Of particular concern is the cross contamination of carcasses with faecal organisms as evidenced by the $\log$ A total coliform counts and Escherichia coli counts (Table 3). This is not uncommon as previous studies noted a similar increase in Escherichia coli number on beef as a result of the slaughtering operations (Abdalla et al., 2009; Gill et al., 2001; Zweifel and Stephen, 2005). Findings from the sampling locations on the carcasses suggest that improvements need to be made on preventive measures in the control activities of the food safety management systems implemented in the abattoirs in Edo State, Nigeria

The high levels of microbial contamination on the carcass contact surfaces (Table 4) were in accordance with different studies (Gill et al., 2001; McEvoy et al., 2004) which reported food contact surfaces as the potential sources of cross contamination. This finding also revealed the need for improvement in the sanitation program implemented in the abattoirs in Edo State, Nigeria. By applying a more sophisticated sanitation program typified by cleaning agents adapted for specific process situations and involving a full step cleaning procedure, the microbial load of the carcass contact surfaces should be reduced.

An overall microbial safety level for the abattoirs in Edo State, Nigeria, which was estimated at 0.83 (Table 5), indicated that values of microbiological parameters exceeded the safe limit and improvements were needed to be made on multiple control activity of the food safety plan.

Values of the hygienic status and microbial safety level obtained in present study, therefore, corroborate the overall poor performance of the food safety management system implemented in the abattoirs in Edo State, Nigeria.

Conclusion: The present study applied a quantitative approach to hygienically assess the current performance of the FSMS implemented in abattoirs in Edo State, Nigeria. It revealed that the level of contamination on bovine carcasses was grossly unacceptable, and as a result, improvements of the current FSMS implemented in these abattoirs were thus inevitable, especially due to the fact these abattoirs are situated in a tropical geographical location with ambient temperatures conducive for the growth of microorganisms, which can rapidly render beef unsafe for human consumption.

\section{REFERENCES}

Abdalla, M. A., Suliman, S. E., Ahmed, D. E., Bakhiet, A. O. (2009). Estimation of bacterial contamination of indigenous bovine carcasses in Khartoum (Sudan). African Journal of Microbiologial Research 3: 882 - 886.

Alonge, D. O. (2001). Slaughtering and handling of meat. In: Meat and Milk Hygiene. $\quad 2^{\text {nd }}$

ed. Farmcoe Publishers, Ibadan Nigeria. PP. $133-147$.

Anonymous, (2001). Commission Decision of 8 June 2001 (2001/471/EC). Official Journal of the European Communities L165: 48 - 53.

Barrow, G. I. and Feltham, R. K. A. (2003). Cowan and Steel's Manual of Medical Bacteria. $3^{\text {rd }}$ ed. Cambridge University Press. 352 PP.

Bryant, J., Bereton, D. A., and Gill, C. O. (2003). Implementation of a validated HACCP system for the control of microbiological contamination of pig carcasses at a

\footnotetext{
${ }^{*}$ AKINNIBOSUN, FI.; ${ }^{2} I M A D E, O S$.
} 
small abattoir. The Canadian Veterinary Journal 44: 51 - 55.

Bwala, D. G., McCrindle, C, Fasina, F. O., and Ijagbone, I. (2015). Abattoir characteristics and seroprevalence of bovine brucellosis in cattle slaughtered at Bodija municipal abattoir, Ibadan, Nigeria. 7: $164-168$.

Edwards D., Hector, D. A., Norman, G. A., and Silverside, D. (1979). Slaughter

Facilities for Tropical Conditions: $A$

Guide to the Selection and Costing of

Appropriate Systems. Tropical Product Institute, London. 68 PP.

Fasanmi, G. O., Olukole, S. G., and Kehinde, O. O. (2010). Microbial studies of table scrapings from meat stalls in Ibadan metropolis, Nigeria: Implications on meat hygiene. African Journal of Biotechnology 9: 3158 - 3162 .

Gill, C. O. and Jones, T. (2000). Microbiological sampling of carcasses by excision or swabbing. Journal of Food Protection 63: 167 - 173.

Gill, C. O., Bryant, J., and Badoni, M. (2001). Effects of hot water pasteurizing treatment on the microbiological condition of manufacturing beef used for hamburger patty manufacture. International Journal of Food Microbiology 63: $\quad 243-256$.

Govender, R. (2014). A hazard analysis methodology for the South African abattoir hygiene management system. British Food Hygiene 116: $2026-2047$.

Hong, C. H., Todd, E. C., and Bahk, G. J. (2008). Aerobic plate count as a measure of hazard analysis critical control point effectiveness in a pork processing plant. Journal of food protection 71: $1248-1252$.

ISO, (2003). Carcass sampling for microbiological analysis. In: Microbiology of Food and Animal Feeding Stuffs. (ISO 17604: 2003). British Standards Institution, London.16 pp.
ISO, (2004). Horizontal methods for sampling techniques from surfaces using contact plates and swabs. In: Microbiology of Food and Animal Feeding Stuffs. (ISO 18593:2004). British Standards Institution, London. 14 PP.

Jacxsens, L., Kussaga, J., Luning, P. A., VanderSpiegel, M., and Uyttenddaele, M. (2009). A microbial assessment scheme to measure microbial performance of food safety management systems. International Journal of Food Microbiology 134: $113-125$.

Kilsby, D. C. and Pugh, M. E. (1981). The relevance of the distribution of microorganisms within batches of food to the control of microbiological hazards from food.

Journal of Applied Bacteriology 51: 345 - 354.

Luning, P. A. and Marcelis, W. J. (2007). A food quality management functions model from a technology managerial principles and perspective. Trends in Food Science and Technology 18: 159 - 166.

McEvoy, J. M., Sheridan, J. J., Blair, I. S., and McDowell, D., A. (2004). Microbial contamination on beef in relation to hygiene assessment based on criteria used in EU Decision 2001/471/EC. International Journal of Food Microbiology 92:217 - 225.

Pinillos, R. G. and Jukes, D. J. (2008). Hygiene Assessment System (HAS) scores- An analysis of the available data from English slaughter houses. Food Control 19: 806 816.

Zweifel, C. and Stephen, R. (2005). Microbiological contamination of cattle and pig carcasses at five abattoirs determined by swab sampling in accordance with EU Decision 2001/471/EC. Meat Science 69: 559 - 566. 